УДК 130.2

DOI: $10.26565 / 2306-6687-2020-61-02$
Tytar Olena V.

D. Sc. in Philosophy, Professor of the Department

of Theory of Culture and Philosophy of Science

V. N. Karazin National University

6, Svobody sqr. 61022, Kharkiv, Ukraine

E-mail: tytarolena77@gmail.com

ORCID: http://orcid.org/0000-0002-1951-7830

\title{
PHILOSOPHICAL ASPECTS OF MODERN TOURISM CULTURE
}

Purpose. To characterize the phenomenon of modern tourism from a philosophical standpoint, to identify those anthropological changes that bring tourism to modern global culture, to identify changes in cultural identities occurring on a global dimension under the influence of the tourism industry. Scientific novelty. The hypothesis is that the development of the cultural tourism industry first leads to the emergence of performative identities, when it is possible to speak not simply of the emergence of multiple identities, but of the fact that ethnic and social identities are changing. Opposing external and internal travel, it is argued that global tourism initially relied on an external horizontal type of travel, only recently has tourism embraced external and internal travel, thereby becoming an education of education and selfdevelopment. Five main types of tourists are distinguished and characterized, their philosophical and anthropological characteristics. The three types are born in the modern and are related to the horizontal way of travel, it is a vagrant, a missionary, an artist. The postmodern era is characterized by the emergence of a new type of tourist - a creative personality, as well as fundamental anthropological changes concerning the flaner, the flaner is already looking not so much visual impressions as it was in modern times, how many impressions that can cause psychological shifts, anthropological changes through shock events of the Real. It is determined that the philosophical and anthropological characteristics of modern tourism include: "controlled risk", "atmospheric" as an attraction to a holistic cultural complex, replacement of recreational tourism with tourism of self-improvement and education. It is revealed that for the XIX century there are two new types of tourists - the flaner and the creative personality. Flaner is not about traveling as such, but about watching life without trying to change it. The creative personality, watching life, changes him and himself, the identities of such a person are in principle multiple, and therefore variable depending on one or another environment and particular needs.

Keywords: identity, tourism, philosophical anthropology, philosophy of tourism, anthropological turn, globalism.

Титар Елена Владимировна

доктор философских наук, профессор

кафедры теории культуры и философии науки

Харьковского национального университета

имени В. Н. Каразина

Харьков, площадь Свободы, 6, 61022

E-mail: tytarolena77@gmail.com

ORCID: http://orcid.org/0000-0002-1951-7830

\section{ФИЛОСОФСКИЕ АСПЕКТЫ СОВРЕМЕННОЙ КУЛЬТУРЫ ТУРИЗМА}

Цель. Охарактеризовать явление современного туризма с философской позиции, выявить те антропологические изменения, которые приносит туризм в современную глобальную культуру, определить изменения культурных идентичностей, происходящие в глобальном измерении под влиянием индустрии туризма. Научная новизна. Доказывается гипотеза, что развитие культурной индустрии туризма прежде всего приводит к

(C) Tytar O. V., 2020 
появлению перформативних идентичностей, когда можно говорить не просто о появлении множественных идентичностей, а о том, что этнические и общественные идентичности становятся изменчивыми. Противопоставляются внешнее и внутреннее странствования, доказывается, что глобальный туризм сначала опирался на внешний горизонтальный тип странствования, только в последнее время туризм стал охватывать внешнее и внутреннее странствования, тем самым становясь туризмом образования и саморазвития. Выделены и охарактеризованы пять основных типов туристов, их философско-антропологические характеристики. Три типа зарождаются в эпоху модерна и связанны с горизонтальным способом странствования, это бродяга, миссионер, художник. Для постмодернистской эпохи характерно зарождение нового типа туриста - креативной личности, а также принципиальные антропологические изменения, касающиеся фланера, фланер уже ищет не столько визуальных впечатлений, как было в модерную эпоху, сколько впечатлений, которые способны вызвать психологические сдвиги, антропологические изменения самости из-за шока визуальной события Реального. Определено, что к философско-антропологических характеристик современного туризма можно отнести: «контролируемый риск», «атмосферность» как привлечение к целостному культурному туристическому комплексу, замену развлекательного туризма на туризм самосовершенствования и образования. Выявлено, что для XXI века характерны два новых разновидности туриста - фланер и креативная личность. Фланер имеет целью не путешествие как таковое, а наблюдение за жизнью, без попыток ее изменения. Креативная личность, наблюдая за жизнью, меняет ее и себя, идентичности такой личности принципиально является множественными, а, следовательно, переменными в зависимости от той или иной среды и тех или иных индивидуальных потребностей.

Ключевые слова: идентичность, туризм, философская антропология; философия туризма, антропологический поворот, глобализм.

\author{
Титар Олена Володимирівна \\ доктор філософських наук, професор \\ кафедри теорії культури та філософії науки \\ Харківського національного університету \\ імені В. Н. Каразіна \\ Харків, майдан Свободи, 6 \\ E-mail: tytarolena77@gmail.com \\ ORCID: http://orcid.org/0000-0002-1951-7830
}

\title{
ФІЛОСОФСЬКІ АСПЕКТИ СУЧАСНОЇ КУЛЬТУРИ ТУРИЗМУ
}

Мета. Охарактеризувати явище сучасного туризму з філософської позиції, виявити ті антропологічні зміни, що приносить туризм в сучасну глобальну культуру, визначити зміни культурних ідентичностей, що відбуваються у глобальному вимірі під впливом індустрії туризму. Теоретинчий базис дослідження складається 3 праць, присвячених сутності та атрибутам колективних та індивідуальних ідентичнгостей. Окремий блок становлять праці, присвячені філософії туризму та соціально-культурним та антропологічним змінам, що виникають у сучасних суспільствах під впливом глобалізації. Теортетичний базис дослідження заснований на уявленнях про культурну ідентичність туриста як принципово мінливу та перформативну. Наукова новизна. Доводиться гіпотеза, що розвиток культурної індустрії туризму насамперед призводить до появи перформативних ідентичностей, коли можна говорити не просто про появу множинних ідентичностей, а про те, що етнічні та громадські ідентичності стають мінливими. Протиставлюється зовнішнє та внутрішнє мандрування, доводиться, що глобальний туризм спочатку спирався на зовнішній горизонтальний тип мандрування, лише останнім часом туризм став охоплювати зовнішне та внутрішне мандрування, тим самим стаючи туризмом освіти та саморозвитку. Виокремлено та охарактеризовано п'ять основних типів туристів, їх філософсько-антропологічні характеристики. Три типи зароджуються у добу модерну і пов'язані з горизонтальним способом мандрування, це бродяга (волоцюга), місіонер, художник. Для постмодерної доби характерно зародження нвого типу туриста - креативної особистості, а також принципові антропологічні зміни, які стосуються фланера, фланер вже шукає не стільки візуальних вражень, як було у модерний час, скільки вражень, що здатні викликати психологічні зрушення, антропологічні зміни через шок візуальної події Реального. Визначено, що до філософсько-антропологічних характеристик сучасного туризму можна віднести: «контрольований ризик», «атмосферність» як залучення до цілісного культурного комплексу, заміну розважального туризму на туризм самовдосконалення та освіти. Виявлено, що для XXI століття характерні два нові різновида туриста - фланер та креативна особистість. Фланер має на меті не 
подорож як таку, а спостереження за життям, без спроб його зміни. Креативна особистість, спостерігаючи за життям, змінює його та себе, ідентичності такої особистості принципово є множинними, а отже змінними в залежності від того чи іншого середовища та тих чи інших індивідуальних потреб.

Ключові слова: ідентичність, туризм, філософська антропологія, філософія туризму, антропологічний поворот, глобалізм.

Relevance of research. Collective identities remain the mainstay of national cultures, national selfdetermination. Recently, globalization trends are contributing to the transformation of collective identities, creating a unified, tourist-attractive, world culture, while the creation of new forms of tourism influence on mass culture and identities remain unaddressed as the tourism economy exerts a "soft" influence on the media and mass consciousness.

Formulation of problem. Tourism in modern society is not just forming a special touristic culture, it is becoming universal while globalizing and penetrating into other cultural spheres. As it could be already mentioned as for some countries that they live not only at the expense of tourism, but inside tourism as a special advertising simulacrum, so culture of tourism is becoming one of the most prosperous and promising sectors of modern society.

Analysis of recent publications, level of research on the problem. Tourism culture, its social, anthropological and philosophical essence were researched by D. Bell, J. Mead, T. Parsons, J. Walker, E. Fromm, Z. Bauman [Bauman, 2015; Bauman, 2008], U. Beck [Beck, 2007; Beck, 2001]. As for national scientists, the topic was elaborated in the researches of O. Holovashenko, S. Horsky, O. Doroshko, A. Yemchenko, V. Zinchenko, A. Kozitsky, O. Lugova, Y. Lutsky, M. Knyazev [Pazenok (ed.), 2005]. Problems of cultural identity transformations are most fully revealed in the works of D. Bell, U. Beck [Beck, 2007; Beck, 2001], and Z. Baumann [Bauman, 2015; Bauman, 2008], V. Kusherts, A. Giddens, and E. Gellner. In the publications presented, the philosophical and anthropological characteristics of modern tourism are insufficiently analyzed, in most publications it is noted that the culture of tourism influences collective and individual identities, but the anthropological mechanisms of such transformations remain out of the focus of researchers.

Purpose and objectives of the article are to determine basic philosophical and anthropological characteristics of modern tourism, its interaction with globalism, possible transformations of identities under the influence of the advanced touristic cultural industry.

Outline of the main material and scientific results of the study. U. Beck [Beck, 2001] begins his investigations by arguing that globalization is an erosion of old well-known cultural processes, including national state, but immediately notes that these are not only possible erosions but also a phenomenon of cultural transformation: "For, as we have seen, globalization means one thing above all others: denationalization - that is, erosion of the national state, but also its possible transformation into the transnational state" [Beck, 2001, pp. 31-34].

Being becomes a design and globalization creates new values, where openness means, first and foremost, the destruction of institutions and borders: "Globalization means lessons learned from the demolition of the boundaries of everyday activity in different spheres of economy, information, ecology, technology, transcultural conflicts and civil society, thus, meaning basically something known long ago and at the same time unclear, that is difficult to understand, something that changes our daily life by irresistible force and makes everyone adjust and respond to these changes" [Beck, 2001, pp. 86-88].

Despite such devastations and transformations that threaten the very concept of cultural identity in the age of globalization, U. Beck remains to be a moderate optimist, calling after $\mathrm{H}$. Ball a new era of globalization "new Middle Ages": creation of effective crossover identities, and on the basis of world market some transnational societies and new connections must be created: "social and political ties and identities must be considered as being crossed in terms of global, regional, national and local starting points and concepts of action" [Beck, 2001, p. 198].

New stage of globalization is to penetrate further into the culture of information technologies: "Globalized strategy is also possible with new information technologies. They allow for continuous coordination through video conferencing, e-mails and so on" [Beck, 2007, p. 400]. Other distinctive features of globalization are marked as qualitative variability of globalized world, its instability and individuality. First of all, these are works and concepts of Z. Bauman, who speaks of globalized society as 
individualized and mobile, pointing to the "turn-round", "variability" of modernity [Bauman, 2015; Bauman, 2008].

V. Liakh directs to deep philosophical study of tourism problems in domestic philosophy, and behind the phenomenon of modern travelling he sees not only spread of globalization and new ways of cultural adaptation to it, but also existential loneliness and existential experiment [Pazenok, 2005, pp. 170-171] as testing one's own capacity, even going beyond one's own capacity - such overcoming of anthropological boundaries has always been a particular philosophical sphere of interest. Globalization first of all turns to external travelling, these trips turn into tourism, and in general, global culture can be defined as a culture based on the cult of tourism, the spiritual component here is offset by the novelty of discovery and aesthetics of travel. According to the United Nations, tourism includes all kinds of movements of the population, not related to the permanent change of place of residence and work, these are trips and travels for the purpose of rest, participation in scientific, business, cognitive, cultural gatherings [Uvarov\&Borisov, 1990].

Mixture of tourism and self-search as a certain cultural practice of self-expression characterizes current stage of globalization. Tourism preserves from the pilgrimage deep philosophical and existential roots of selfsearch and the search of deep impressions is able to change the individual and society on the whole. At the same time, tourism embodies modern and postmodern searches of one`s place in life, fragmentation and tornness of perception, kaleidoscopic experience gained.

More profoundly the question of changing a culture of stability into the culture of travelling and tourism was explored by Zygmunt Bauman [Bauman, 2015; Bauman, 2008]. In particular, Z. Bauman links tourism as a cult to the emergence of four postmodern cultural figures that replace modern heroes, they are: a flanner, a vagabond, a tourist and a player. They are not only inherent in postmodern, but it is during postmodern times that these four figures influence social and cultural communication most. For Z. Bauman [Bauman, 2008], and we agree with his point of view, principal difference between vagabond and tourist is that tourist's life experience is always safe and planned, unlike the chaotic social movements of vagabond, who does not rely on public guarantees.

Z. Bauman [Bauman, 2008] analyzes tourist figure in more detail.

- tourist, like the vagabond, moves from social marginals and social outskirts to the center of social life;

- tourist, like the vagrant, is characterized by certain alienation from social realities and constant movement, tourist has a certain purpose, he embodies his dream, the vagabond avoids existing realities and is guided not by dreams, but by illusions;

- tourist searches for adventures and for new impressions, realizing that he is able to get rid of new circumstances of his life at his will every moment, the vagabond avoids troubles and ordinary lifestyle, which in particular implies responsibility, he follows not a desire, but avoiding same impressions, in most cases negative ones;

- tourist can be identified by "seat belts" that transfer any experience into safe, thoughtful, comfortable adventure, from where many thoughtful and guaranteed emergency exits exist, the vagabond cannot count on safety and happy endings in his travels;

- tourists domesticate danger, the world is filled with comfortable exotics, the main task of the world is to provide tourists with pleasure and new impressions, a new non-traumatic experience. The vagabond's experience is fundamentally traumatic and chaotic, without any sorts of "seat belts".

- for tourist the whole world called "do-it-by-yourself" is created, where elements of the mosaic are already given, and the task of tourist is to build them according to his wishes and expectations, the main task of such world is to make an "atmospheric» tour and entertain the tourist, after that he will return to his own house while a vagabond who has no fixed places of residence cannot count on it [Bauman, 2008].

In another paper, Z. Bauman [Bauman, 2015] rightly points out that modern society is built on economic growth, it always expects it: "Economic growth is the only way to meet the challenges, and perhaps to solve all the problems that will arise from human coexistence" [Bauman, 2015, p. 14]. As according to both Aristotle and Bauman people are not equal in nature, rivalry and competition are born ("competition is sublimation of war", "rivalry is ... necessary and is the sufficient condition for social justice" [Bauman, 2015, p. 12], competition leads to new waves of consumerism as the only habitual way of achieving happiness (comfort), "continuous growth of consumption..is the only and the most important and effective way to satisfy the urge of man to 
happiness"), where consumption is gradually shifting from the consumption of tangible objects to the consumption of impression, which of course will be best satisfied by recreation and entertainment industry.

Competition leads to pursuit of happiness as comfort and space at the same time, the contradiction of tourism as "changing home" leads to cooperation of capitalist competition and tourism as cultural practice: "when tourism becomes a lifestyle, when experienced impressions only exacerbate the appetite for further excitement, when the threshold of irritation grows and every new irritation must be stronger than the previous one - the possibility of making a dream of home true is as frightening as if it never comes to fruition. Home longing is not the only feeling of tourist, another one is fear of getting attached to home, to the place, and therefore to leave the opportunity to get away from it. "Home" flutters on the horizon of tourist's life as a wild mix of shelter and prison" [Bauman, 2008, p. 54]. Space is searched for by the tourist, and home can act only as temporary space: ideal model of modern tourist is a snail, that can constantly move further, while carrying the house behind. The snail, at the same time, must be frivilous and seductive enough, and be able to transform depending on the path chosen.

Tourism gives happiness of consumption and feeling of temporary home, road gives a sense of being busy and overcomes loneliness, a modern person no longer counts on love and home, but the need to take care of someone transforms into the need to take care of road and impression. That is, without enduring the risk of relationship with another person, modern tourist chooses the risk of relationship with the road; unlike love to gadgets such love also requires hope and dedication: "However, unlike love to electronic devices, love of human to human means devotion, agreeing to risk, ability for self-sacrifice; it signifies choice of the unknown, uneven and slippery road in the hope - and in the determination - to share one's life with another person" [Bauman, 2015 , p. 20]. Due to its cognitive and life-oriented functions, tourism becomes of particular importance in the information (V. Kusherets) and informational (M. Castells) days, when deeper issues of fundamental dialogical nature of human being and communication, education as constant informational search and traveling in the cultural worlds are raised by changing impressions and locations.

Tourism raises a new issue not only of identities, but also of ethics, ethical conduct and creativity in general. Ethical guideline of modern tourism is self-improvement and self-development, where cognitive and cultural values interact closely. In addition, modern tourism not only remains a component of mass culture, but also determines main directions of its development, main prevailing trends. As environmentalists and nature conservationists have been complaining for the last five years that touristic popularity and attractiveness of countries and natural landscapes are now determined by Instagram, those countries or nature preserving corners that unexpectedly become «stars» of Instagram are heavily affected by some purposeful, calculated tourism to fabulous photo shoots, not real life. Residents of Venice, Paris, the Maldives have repeatedly held protests and appealed for preservation of cultural and natural heritage from barbaric tourism, which cares only for beautiful "picture", and it is no longer relevant whether the landscape or artifact itself is preserved afterwards. For several years now, Athens travel agencies have been pouring special stones around the Acropolis, which are disassembled by tourists as authentic "ancient" stones during the day, as they have already been tired of appealing and cautious speeches about the necessity of preserving their antiquities.

Mass culture also emphasizes, first and foremost, the commercial success and economic benefits of tourism, providing employment, new jobs and new consumer goods; tourism is not only becoming a consumer industry, but is generally defining what should be consumed and in what quantity, "the freshest" and the most original impressions of contemplating new tourist attractions are on the top of the consumer pyramid now. Not just a brand, but a tourist attraction is becoming the most valuable asset. In this case, branding mechanisms remind old mechanisms of colonial politics, where now, instead of opposing the metropolis and the colony, there is a juxtaposition of tourist appeal, exoticism, and "gray" everyday life. A cultural value is transformed into the product and effective strategies for its consumption, the cult of youth, beauty, health, and "real world" is appreciated, which reveals supposedly "the same" real functioning behind the virtual picture. Tourist becomes a commercially profitable customer, for the sake of whom the whole performance of exotic (or supposedly "real", as in "reality show") tourist consumption unfolds. Here comes a combination of two trends: tourist's desire to aesthetize the reality, often based on virtual eality models (Instagrams, edited photos, cinematic or advertising images), efforts of cultural tourism industry to transform the whole aesthetic and ethical component (the latest trends are also cognitive and developmental components) into commercial profit. Thus the aesthetic and the creative items become only a component of more sold and popular product in the tourist services market. 
Having "mastered" most of the "beautiful" landscapes, tourism industry continues the route of "humanization" of tourism, offering new methods of self-improvement or getting acquainted with the life path of the most outstanding personalities, or offering new ways of survival under the guidance of a travel company in the most extreme environment ("prison" tourism and Chornobil area as a tourist attraction).

The most requested spheres are development of creativity during or as a result of the tourist journey: tourism industry calls not for worrying about possessions, but caring about impressions that accumulate and make customer a significant person in the labor market, that is, if you hit the road all over Europe, you have acquired much more important social and cultural capital than spending all your money on property and material things or even education. Here, tourism becomes the main means of identity change and transformation, the main and socially significant cultural practice of constructing new variables, they can be called postmodern identities. First of all, tourist is distinguished by his creative identity, even when he or she does not have that identity yet, often the purpose of the journey and the path is to establish that kind of identity. When only monks had a right to have spiritual perfection in Medieval Europe, Bernard Clervos and Dante were the first to speak of the worldly path of spiritual virtue, offering to supplement the spiritual journey with earthly paths. Protestantism develops this idea in the form of spiritual pilgrimage. Byzantine and Ukrainian traditions contrast the path of horizontal (in holy places) and vertical (by spiritual authorities) travel. We already see a certain synthesis of a new journey as a spirit journey that purifies the spirit in G. Skovoroda`s works.

Journey of man into the world is the life mode of mastering the eternal "sophiety" of creation as hypostasis of the infinite wisdom of the Creator. Metaphor of journey is very vividly and fully represented in the works of G. Skovoroda. Semantic tension here is in the direction of opposing "external" (horizontal) and "internal" (vertical) travel. The thinker contrasts ancient and Christian paradigms of cognition as «external» and «internal» journeys. The world catches on to its tenets of the unknown, unconcealed in the essence of being. In the journey, one must grasp the eternal and be guided by it. The eternal is of invisible, blissful nature, the truth, or God, who is dispelled invisibly throughout everything as a primary foundation. The idea of ehe divine world as the ultimate goal of any true journey according to G. Skovoroda coexists with urban metaphor of the garden. For example, in the 17th song, G. Skovoroda calls "Oh Christ! Don't let me burn in the hell! Let me live in your heaven hail" [Skovoroda, 1994, p. 65]; the divine is embodied from the third song in the form of "my hail", "my garden" [Skovoroda, 1994, p. 51]. The one who got the second, spiritual birth, is similar to the ground of the garden in spring, which comes to life for a new life: "His soul is God's hail, his soul is God's garden" [Skovoroda, 1994, p. 51]. When the divine can more or less unequivocally relate to the flowering garden of the human soul, urban metaphor is dual, it can have dangers; only God's hail, «mountain» republic will be positive for sure, all the paths, right up to the «mountain» republic, tend to transform, change people - "because cities, though high, will turn to the sea of despair. And the gates, though wide, will lead to captivity" [Skovoroda, 1994, p. 59]. In order to reach Jerusalem, Zion must choose a "narrow path", take the part, share "God with David", as song 22 [Skovoroda, 1994, p. 70] insists, then "You by yourself ... is the Holy Spirit and the city" [Skovoroda, 1994, p. 67]. Therefore, there is a distinction between two cities - the sinful and the divine ones and a wellknown phrase "Every city is given its customs and rights" - the sinful city has a series of temptations, and the "blessed husband" has "conscience as a pure crystal" [Skovoroda, 1994, p. 58]. Greek Orthodox tradition, embraced in Ukraine, transformed into dominant identities, emphasizes the need for active spiritual activity, journey contributes to the rebirth of both individual and peoples.

Having overcome the experience of Protestantism, Europe is turning to the figure of pilgrim in a new status: it is a tourist, but a tourist whose purpose are foremost spiritual goals and self-improvement. At the beginning of the 21 st century, we see an increase of interest in tourism not only as a commercial event, but also as a spiritual journey, which transforms one's established life and eventually transforms one's identification practices. Creative identities of modernity are actively analyzed by Richard Florida [Florida, 2016], who rightly notes that the tourist of the early 21 st century is marked by his creative identity that changes all spheres of culture. We are witnessing the emergence of a new creative class, the formation of which often happens not through family, upbringing in a nation-state or through educational practices, but through tourism in all its forms. Tourism is becoming a new means of building rationality and critical thinking, leading to life experiments of the representatives of creative class and the development of new ways of improvement through test-travels, empathy, business or charity. 
Richard Florida [Florida, 2016] writes about formation of a particular creative class and creative way of interacting with life, where tourism as well as search for oneself plays the leading role: "The core of the creative class are people in the technical domain, architecture, design, education, music and entertainment industries, whose economic function is to create new ideas, new technologies and new creative content. In addition to the core, creative class also includes a large group of creative professionals working in business and finance, law, medicine and related fields. These people are involved in complex tasks that require considerable independence of thinking and high levels of education and human capital. Further, all the members of the creative class artists or engineers, musicians or cyber-specialists, writers or entrepreneurs - share a common creative ethos for which creativity, individual characteristics and personal merit are important..., creative class earns money by designing and creating something, and performs it with a great deal of autonomy and flexibility" [Florida, 2016, p. 6-7]. Such creative identity is based on the harmonious combination of many social roles and trying to test oneself in different locations and circumstances, the same person can be simultaneously a writer, a mountaineer, a consultant, a researcher, an electronic, an adherent of ethnic music or jazz, an artisan, a cook, an owner of a beer restaurant, etc. The list is far from being exhaustive and the journey, immersion each time in new circumstances and new countries, allows such a person to feel one's identity as belonging to the creative class. Accordingly, new forms of experience are included, tourism as a cultural practice is most relevant to the lifestyle of the new creative class.

As R. Florida rightly points out, "because of our creative identity, we feel the growing need for a lifestyle built on creative experience. We are not satisfied with the former hard boundaries between work, home and leisure" [Florida, 2016, p. 42]. While style and organization of the previous era was based on conformism and rigid stratification, the new way of life fosters individualism, self-development and tolerance, a diverse experience becomes the key, and tourism is the best practice in gaining it. It is a peculiar mixture of capitalist, bohemian and intellectual values; we are not just overcoming them but are moving to the new level of social and cultural organization: "Under the influence of the creative ethos, we combine work and lifestyle to create a creative identity. In the past, people identified themselves through several main categories: profession, place of work, marital status (husband, wife, father, mother). Now they are more likely to express themselves through a haphazard array of creative activities; interviews which I have conducted reveal this fact" [Florida, 2016, p. 42].

Scientific novelty. The philosophical and anthropological characteristics of modern tourism include: "controlled risk", "atmospheric" as an attraction to a holistic cultural complex, the replacement of recreational tourism with tourism self-improvement and education, the emergence of creative personality-tourist, change the idea of flannery - "point of observation" to reality (landscapes, cities, personalities or even businesses) represented on the Internet and social networks, the flyer takes on the functions of a journalist and a "search engine with experience". The developed cultural industry of modern tourism leads not only to the transformation of existing identities, but to the emergence of multiple identities. Two new varieties of tourists, characteristic of the 21st century, are distinguished and researched in terms of cultural identities - the flanner and the creative personality. Flaner is not about traveling as such, but about watching life, without trying to change it. The creative personality as a developed individual and a representative of the developed community has been emerging for the last thirty years, as well as observing life, the creative personality changes it, as well as changes itself, the identities of such a person are in principle multiple.

Conclusions. Modern tourism is a complex social and cultural phenomenon that changes culture and the existing system of values in general. Globalism enables tourism, with the help of common mass culture, advanced transportation, entertainment, media and social media, to create a global traveler-tourist world that can act as a vagabond, missionary, artist (creative personality), flanner, or creative personality prone to self-testing and self-education. The vagabond has no «seat belts» and no definitive opportunity to direct his experience, the missionary broadcasts European values and a certain established way of behavior; the artist subordinates any journey to the development of his skills and his highest cultural status, thus, the fact that these three figures bring the experience of Modern and Postmodern together, is a consequence of the development of modernization and globalization in the modern world. The player as a separate figure, in our opinion, dissolves in the three characters mentioned above, the element of the game is characteristic to the development of modernist style, in Postmodern it takes on new forms - game only is no longer able to satisfy most needs of Postmodern personality. 21st century is characterized by two new types of tourists - flanner and creative personality. Emergence of the figure of the flanner is associated with the nineteenth century, but then flanner could only 
belong to a narrow layer of elite and bohemian. Flanner is not for travelling as it is, but for watching life without trying to change it. Creative personality as a developed individual and a representative of the developed community has emerged for the last thirty years, also by observing life; creative personality changes it and also changes oneself, the identities of such personality are fundamentally multiple, and therefore variable depending on some environment and some individual needs.

Philosophical and anthropological characteristics of modern tourism include: "controlled risk", "atmosphere" as an attraction to a holistic cultural complex, replacement of entertainment tourism for tourism of self-improvement and education, emergence of creative personality-tourist, changing of the idea of flannery as watching "points of observation" to reality (landscapes, cities, personalities or even businesses) presented in the Internet and social networks, flanner takes on functions of a journalist and a "searcher of real impressions".

Developed cultural industry leads not only to transformation of existing identities, but to emergence of multiple identities, touristic attractiveness of different "honed", traditional and newly formed identities; moreover, global processes can now take place not only around economic feasibility, but also around tourist attractiveness, accessibility and tourist advertising in mass media of different localities or countries. To add, the more distinctive and colorful the national identities of such countries are, the more touristic they become. Also, the emergence of the creative class dictates change in identity when national traits can act as national strategies for tourism development and communication.

\section{СПИСОК ВИКОРИСТАНИХ ДЖЕРЕЛ}

Бауман 3. Идет ли богатство немногих на пользу всем прочим? / пер. с англ. Н. Эдельмана. Москва: Логос, 2015. 162 с.

Бауман 3. Текучая современность / пер. с англ. Ю. Асочаков. Санкт-Петербург: Питер, 2008. 240 с.

Бек У. Власть и ее оппоненты в эпоху глобализма. Новая всемирно-политическая экономия / пер. с нем. А. Григорьева и В. Седельника. Москва: Прогресс-Традиция, Территория будущего, 2007. 464 с.

Бек У. Что такое глобализация? Ошибки глобализма - ответы на глобализацию / пер. с нем.

А. Григорьева и В. Седельника. Москва: Прогресс-Традиция, 2001. 303 с.

Сковорода Г. Твори. У 2-х т. Київ: АТ Обереги, 1994. Т. 1. 528 с.

Уваров В. Д. Борисов К. Г. Международные туристские организации. Москва: Международные отношения, 1990. $288 \mathrm{c}$.

Філософські нариси туризму / за ред. В. С. Пазенка. Київ: Український Центр духовної культури, 2005. 328 c.

Флорида Р. Креативный класс, люди, которые меняют будущее / пер. с англ. Н. Яцюк. Москва: МИФ, 2016. 598 с.

\section{REFERENCES}

Bauman, Z. (2015). Does the Richness of the Few Benefit Us All? (N. Edelman, Trans.). Moscow: Logos. (Original work published 2013). (In Russian).

Bauman, Z. (2008). Liquid Modernity. (J. Asochakov, Trans.). St. Petersburg: Piter. (Original work published 2000). (In Russian).

Beck, U. (2007). Power and its opponents in the age of globalism. New World Political Economy. (A. Grigoreva \& V. Sedelnik, Trans.). Moscow: Progress-Tradition and Territory of the future. (Original work published 2005). (In Russian).

Beck, U. (2001). What is Globalization? Mistakes of Globalism - Answers to Globalization. (A. Grigorieva \& V. Sedelnik, Trans.). Moscow: Progress-Tradition. (Original work published 1997). (In Russian).

Skovoroda, Gh. (1994). Works. In 2 volumes. Vol. 1. Kyiv: AT Obereghy. (in Ukrainian).

Uvarov, V. D. \& Borisov, K. G. (1990). International tourist organizations. Moscow: International relationships. (in Russian).

Philosophical Essays in Tourism. (2005). (V. S. Pazenok, Ed.). Kyiv: Ukrainian center of spiritual culture. (In Ukrainian).

Florida, R. (2016). Creative class, people who change the future. (N. Yatsyuk, Trans.). (R. Husainov, Ed.). Moscow: MIF. (Original work published 2002). (In Russian). 